Neurolmages

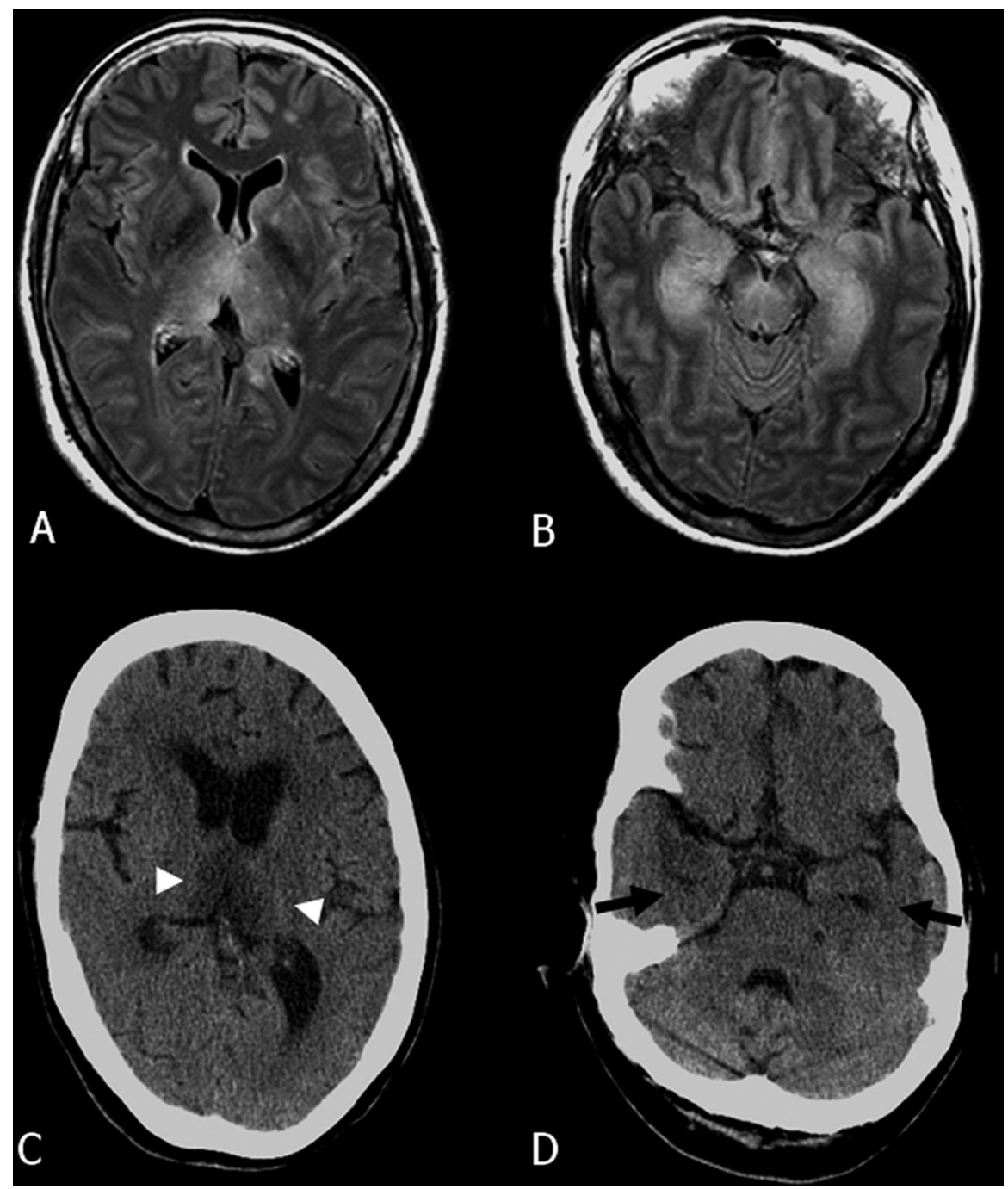

Figure. Fluid-attenuated inversion recovery axial MRI without contrast enhancement shows high-signal lesions in both thalami (A) and bilateral lesions of the medial temporal region and substantia nigra (B). Noncontrast brain CT taken at 4 weeks after initial MRI reveals low attenuation in both thalami (arrowheads) (C) and in both medial temporal regions (arrows) (D). Mild increase of ventricle size is also noted.

\section{Bilateral medial temporal lesions in Japanese encephalitis}

Ki-Young Jung, MD; Chin-Sang Chung, MD; and Kun-Woo Park, MD, Seoul, Korea

A 62-year-old woman presented with headache, fever, and deteriorating consciousness. Brain MRI showed bilateral lesions of the thalamus and substantia nigra. The medial temporal region was also involved bilaterally (figure). The serum hemagglutination

Disclosure: The authors report no conflicts of interest.

Address correspondence and reprint requests to Dr. K.-Y. Jung, Department of Neurology, Korea University Medical Center, Korea University College of Medicine, \#126-1, 5-Ga, Anam-Dong, Seongbuk-Gu, Seoul 136705, Korea; e-mail: jungky@korea.ac.kr inhibition test for Japanese encephalitis (JE) virus was initially negative; the titer was increased to 1:640 10 days later. Therefore, a diagnosis of $\mathrm{JE}$ was made. The patient remained in a vegetative state for 2 months before dying of pneumonia. Medial temporal lesions are seen in herpes simplex encephalitis, paraneoplastic limbic encephalitis, and neurosyphilis. ${ }^{1} \mathrm{JE}$ also commonly produces medial temporal lesions. ${ }^{2}$ However, medial temporal lesions associated with bilateral thalamic or midbrain involvement may be more suggestive of JE, particularly in endemic areas.

1. Scheid R, Voltz R, Vetter T, Sabri O, von Cramon DY. Neurosyphilis and paraneoplastic limbic encephalitis: important differential diagnoses. J Neurol 2005;252:1129-1132.

2. Handique SK, Das RR, Barman K, et al. Temporal lobe involvement in Japanese encephalitis: problems in differential diagnosis. AJNR Am J Neuroradiol 2006;27:1027-1031. 


\section{Neurology}

\section{Bilateral medial temporal lesions in Japanese encephalitis}

Ki-Young Jung, Chin-Sang Chung and Kun-Woo Park

Neurology 2007;68;1319

DOI 10.1212/01.wnl.0000260228.73212.f5

\section{This information is current as of April 16, 2007}

\section{Updated Information \&} Services

References

Subspecialty Collections

Permissions \& Licensing

Reprints including high resolution figures, can be found at: http://n.neurology.org/content/68/16/1319.full

This article cites 2 articles, 0 of which you can access for free at: http://n.neurology.org/content/68/16/1319.full\#ref-list-1

This article, along with others on similar topics, appears in the following collection(s):

Encephalitis

http://n.neurology.org/cgi/collection/encephalitis

MRI

http://n.neurology.org/cgi/collection/mri

Viral infections

http://n.neurology.org/cgi/collection/viral_infections

Information about reproducing this article in parts (figures,tables) or in its entirety can be found online at:

http://www.neurology.org/about/about_the_journal\#permissions

Information about ordering reprints can be found online:

http://n.neurology.org/subscribers/advertise

Neurology ${ }^{\circledR}$ is the official journal of the American Academy of Neurology. Published continuously since 1951, it is now a weekly with 48 issues per year. Copyright . All rights reserved. Print ISSN: 0028-3878. Online ISSN: 1526-632X.

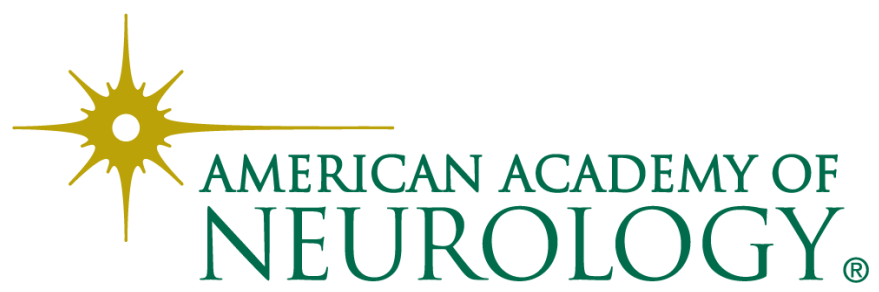

